\title{
Kemampuan Sitotoksik dan Profil Kromatogram Umbi Sarang Semut (Myrmecodia Pendans Merr. \& Perry) Setelah Diiradiasi Gamma
}

\section{Cytotoxic Potencial and Chromatogram Profile of Sarang Semut Tuber (Myrmecodia Pendans Merr. \& Perry) After Gamma Irradiation}

\author{
Ermin Katrin Winarno ${ }^{1}$, Siva Fauziah ${ }^{2}$, Susanto ${ }^{1}$, dan Hendig \\ Winarno $^{1}$ \\ ${ }^{1}$ Pusat Aplikasi Isotop dan Radiasi, BATAN \\ Jl. Lebak Bulus Raya No. 49, Jakarta 12440 \\ ${ }^{2}$ Fakultas Farmasi, Universitas Pancasila \\ Jl. Jagakarsa, Srengseng Sawah, Jakarta Selatan \\ E-mail : erminkk@batan.go.id \\ Diterima 07-10-2015; Diterima dengan revisi 28-10-2015; Disetujui 20-11-2015
}

\begin{abstract}
ABSTRAK
Kemampuan Sitotoksik dan Profil Kromatogram Umbi Sarang Semut (Myrmecodia Pendans Merr. \& Perry) Setelah Diiradiasi Gamma. Umbi sarang semut (Myrmecodia pendans Merr. \& Perry) memiliki aktivitas sitotoksik. Salah satu usaha pengawetan simplisia umbi sarang semut dilakukan dengan iradiasi gamma. Penelitian ini bertujuan untuk mempelajari pengaruh iradiasi gamma pada sitotoksisitas dan profil kromatogram fraksi aktif dari umbi sarang semut. Serbuk kering umbi sarang semut diiradiasi gamma dengan beberapa macam dosis radiasi yaitu : 0 (kontrol); 5; 7,5; 10; dan $15 \mathrm{kGy}$. Percobaan dilakukan dengan dua kali ulangan untuk masing-masing dosis. Setelah iradiasi, serbuk dimaserasi bertahap berdasarkan tingkat kepolarannya dengan $n$-heksan, etil asetat, dan etanol. Setiap ekstrak diuji aktivitas sitotoksiknya terhadap sel leukemia L1210. Dari hasil yang diperoleh didapatkan bahwa ekstrak etanol merupakan ekstrak yang paling aktif (IC50 $9,88 \mu \mathrm{g} / \mathrm{ml}$ ) dibandingkan ekstrak $n$-heksan (IC50 23,44 $\mu \mathrm{g} / \mathrm{ml}$ ) dan etil asetat (IC50 17,32 $\mu \mathrm{g} / \mathrm{ml}$. Ekstrak etanol dari masing-masing dosis difraksinasi secara kromatografi kolom menghasilkan 7 fraksi. Berdasarkan uji aktivitas sitotoksik fraksi-fraksi tersebut, fraksi 1 adalah fraksi yang paling aktif (IC50 $\leq 3,23 \mu \mathrm{g} / \mathrm{ml}$ ). Pada identifikasi KLT-densitometri dari fraksi 1 dan ekstrak etanol mengalami penurunan dan kenaikan bercak setelah diiradisi. Hasil kromatogram fraksi 1 dari KCKT menunjukkan bahwa puncak utama mengalami penurunan setelah diiradiasi. Dosis maksimum untuk iradiasi umbi sarang semut tanpa merusak aktivitas sitotoksiknya terhadap sel leukemia L1210 adalah $5 \mathrm{kGy}$.
\end{abstract}

Kata kunci : iradiasi gamma, ekstrak dan fraksi etanol umbi sarang semut (Myrmecodia pendans Merr. \& Perry), sel kanker Leukemia L1210, IC50, aktivitas sitotoksik, profil kromatogram.

\begin{abstract}
Cytotoxic Potencial and Chromatogram Profile of Sarang Semut Tuber (Myrmecodia Pendans Merr. \& Perry) After Gamma Irradiation. Sarang semut tuber (Myrmecodia pendans Merr. \& Perry) has cytotoxic activity. Preservation efforts of sarang semut tuber was performed with gamma irradiation. The research purposed to study the effect of gamma on cytotoxic activity againts leukemia L1210 cell lines and chromatogram profiles of sarang semut tuber (Myrmecodia pendans Merr. \& Perry). The dried sarang semut tuber were gamma irradiated with a variety of doses of $5 ; 7.5 ; 10$; and $15 \mathrm{kGy}$. The experiments were performed with two replicates for each dose. Then samples were macerated with solvent by
\end{abstract}


gradient polarity with $n$-hexane, ethyl acetate, and ethanol. Extracts were tested againts the leukemia L1210 cell lines. From the results obtained showed that the ethanol extract was the most active againts leukemia L1210 cell lines (IC50 $9.88 \mu \mathrm{g} / \mathrm{ml}$ ) compared with $n$-heksan (IC50 $23.44 \mu \mathrm{g} / \mathrm{ml}$ ) and ethyl acetate extract (IC50 $17.32 \mu \mathrm{g} / \mathrm{ml}$ ). Ethanol extracts were fractionated by column chromatography, the result were obtained 7 fractions. Based on the cytotoxic activity test for each fraction, the fraction 1 had the highest activity (IC50 $\leq 3.23 \mu \mathrm{g} / \mathrm{ml}$ ). The identifications of ethanol extract and fraction 1 by CLT-densitometry showed that the spots area increased and decreased after gamma irradiation. The chromatogram profile of fraction 1 showed that the major peak area decreased after irradiation. The maximum irradiation dose without damaging the cytotoxic activity of sarang semut tuber againts leukemia L1210 cell lines was $5 \mathrm{kGy}$.

Key words : gamma iradiation, extract and fraction ethanol sarang semut tuber (Myrmecodia pendans Merr. \& Perry), , leukemia L1210 cell lines, IC50, cytotoxic activity, chromatogram profile.

\section{PENDAHULUAN}

Sarang semut (Myrmecodia pendans Merr.\& Perry) merupakan salah satu tanaman obat bersifat epifit yang tumbuh di Indonesia dan berpotensi sebagai anti oksidan dan mengatasi penyakit kanker (1). Ekstrak rebusan air dari umbi sarang semut dapat menyembuhkan beragam penyakit seperti mimisan, tukak lambung, wasir, tumor, kanker, jantung, TBC, rematik, gangguan asam urat, stroke, maag, gangguan fungsi ginjal dan prostat. Selain itu juga, terbukti dapat memperlancar air susu ibu (ASI), meningkatkan gairah seksual bagi pria maupun wanita dan memperlancar haid dan mengatasi keputihan (2).

Multi khasiat sarang semut jenis Myrmecodia pendans diduga kuat berkaitan dengan kandungan senyawa aktifnya, terutama dari golongan flavonoid, tanin, tokoferol, multi-mineral $(\mathrm{Ca}, \mathrm{Na}, \mathrm{K}, \mathrm{P}, \mathrm{Zn}$, $\mathrm{Fe}, \mathrm{Mg}$ ) dan polisakarida. Mekanisme kerja senyawa flavonoid dalam mengatasi kanker yaitu dengan membuat karsinogen tidak aktif, penghambat siklus sel, dan induksi apoptosis. Selain itu, Myrmecodia pendans juga mengandung tokoferol yang berefek antioksi dan efektif. Tokoferol berfungsi sebagai antioksidan dalam menangkal radikal bebas dan sebagai antikanker. Dilihat dari kandungannya, maka sarang semut hampir bisa mengatasi berbagai jenis kanker (3). Sarang semut merupakan tanaman obat yang digunakan untuk mengobati berbagai jenis kanker dan tumor, seperti kanker otak, hidung, payudara, lever, paru-paru, usus, rahim, kulit, prostat, dan kanker darah (2).

Fraksi air dari umbi sarang semut telah diuji toksisitasnya dengan metode Brine Shrimp Lethality Test menghasilkan $\mathrm{LC}_{50} 37,03 \mathrm{ppm} / \mathrm{LC}_{50}$ adalah konsentrasi yang menyebabkan kematian pada $50 \%$ binatang percobaan) dan senyawa murni yang telah diisolasi tergolong dalam senyawa glikosida (3). Menurut hasil penelitian, seluruh ekstrak sarang semut menekan proliferasi sel tumor manusia dengan tingkat efektivitas $\mathrm{EC}_{50}$ mencapai $9,97 \mu \mathrm{g} / \mathrm{ml}$ pada ekstrak metanol. Sedangkan $\mathrm{EC}_{50}$ pada ekstrak air $22,3 \mu \mathrm{g} / \mathrm{ml}$ dan pada campuran metanol-air $11,3 \mu \mathrm{g} / \mathrm{ml}$ (4). $\quad \mathrm{EC}_{50}$ adalah konsentrasi obat yang menghasilkan $50 \%$ efek maksimal. Menurut SIMAJUNTAK PARTOMUAN dkk, ekstrak air umbi sarang semut juga memiliki aktivitas sebagai antikanker pada sel HeLa dan sel MCM-B2, berturut-turut diperoleh $\mathrm{IC}_{50}$ sebesar 29,36 ppm dan 74,20 ppm (5). Fraksi aktif dalam umbi sarang semut menunjukkan adanya fenolat, flavonoid, steroid / triterpenoid, dan terkonjugasi senyawa ikatan rangkap (6). Ekstrak etanol sarang semut efektif menghambat proliferasi sel kanker lidah (SPC1). Potensi hambatan proliferasi tertinggi terjadi pada konsentrasi $1000 \mu \mathrm{g} / \mathrm{ml}$ dengan daya hambat sebesar $74,6 \%$ (7). 
Serbuk simplisia termasuk bahan alam yang sangat rentan untuk ditumbuhi mikroba karena mengandung air. Oleh karena itu, para pelaku industri rumah tangga mengeringkan serbuk simplisia dengan penjemuran atau diangin-anginkan. Namun hal tersebut tidak cukup untuk membuat suatu bahan alam dapat bertahan awet dalam waktu yang cukup lama, sehingga diperlukan suatu teknik pengawetan yang dapat mengawetkan bahan alam tersebut tanpa mempengaruhi khasiat yang dikandung di dalamnya. Ada berbagai macam teknik pengawetan yang dapat dilakukan, salah satunya adalah teknik iradiasi. Penggunaan teknik iradiasi untuk pengawetan bahan obat (simplisia) makin meningkat dari tahun ke tahun. Banyaknya industri obat herbal yang menggunakan teknik iradiasi ini disebabkan proses iradiasi ini mudah dilakukan, mudah dikendalikan, tidak memberikan residu, dan memiliki daya tembus yang besar. Iradiasi dapat dilakukan pada bahan yang dikemas dalam bentuk kemasan akhir dan siap dipasarkan sehingga kontaminasi dapat dihindari (8). Beberapa penelitian terdahulu melaporkan tentang hasil dekontaminasi mikroba pada serbuk kering obat herbal dengan iradiasi gamma, iradiasi serbuk kering daging buah mahkota dewa dengan dosis 5-20 kGy tidak ditemukan pertumbuhan bakteri, kapang maupun khamir. Pada kontrol ditemukan pertumbuhan bakteri sebanyak 4,45 x $10^{7}$ koloni/g dan kapang khamir sebanyak 8,13 x $10^{6} \mathrm{koloni} / \mathrm{g}$. Iradiasi telah membunuh sel hidup mikroba di dalam serbuk sehingga tidak dapat membelah diri (9).

Dosis iradiasi $5 \mathrm{kGy}$ pada serbuk benalu teh dapat menghilangkan kontaminan kapang-ragi yang berawal 5,68 x $10^{8} \mathrm{koloni} / \mathrm{g}$, tetapi dosis ini hanya mengurangi jumlah kontaminasi bakteri dari satu siklus $\log$ dari $7,57 \times 10^{9}$ koloni/g menjadi 6,62 x $10^{8}$ koloni/g. Untuk menghilangkan kontaminasi bakteri diperlukan dosis iradiasi yang lebih tinggi. Kontaminasi bakteri dapat dihilangkan sepenuhnya dengan dosis $>7,5 \mathrm{kGy}$. Iradiasi gamma dosis $\geq 5 \mathrm{kGy}$ pada serbuk benalu teh bisa menghambat pertumbuhan kapang dan ragi. Iradiasi dosis < $10 \mathrm{kGy}$ dapat mengurangi kontaminasi mikroba dari benalu teh herbal tanpa mengubah aktivitas sitotoksik ekstrak paling aktif (ekstrak etil asetat) dan fraksi paling aktif (fraksi 2), dan profil kromatogram komponen dalam fraksi 2 dari benalu teh (10).

Pengawetan simplisia obat yang diklaim sebagai obat kanker telah banyak dilakukan dengan menggunakan teknik iradiasi, tetapi pada dosis tertentu diduga dapat merusak zat aktif/metabolit sekundernya. Telah diketahui bahwa iradiasi gamma bermanfaat untuk mendekontaminasi bahan serbuk simplisia, pada penelitian ini Pada pengawetan umbi sarang semut diharapkan iradiasi gamma tidak merusak zat aktif yang berperan sebagai zat inhibisi terhadap pertumbuhan sel leukemia L1210, oleh karena itu perlu diteliti berapa dosis iradiasi maksimum untuk pengawetan serbuk umbi sarang semut tanpa mengubah aktivitas sitotoksiknya. Pengaruh iradiasi gamma pada umbi sarang semut dipelajari apakah menimbulkan perubahan aktivitas sitotoksik terhadap sel leukemia L1210 dan profil kromatogram.

Hasil penelitian tentang pengaruh iradiasi gamma terhadap khasiat zat aktif dalam serbuk umbi-umbian seperti khasiat zat aktif dalam serbuk umbi sarang semut (Myrmecodia pendans Merr.\& Perry) belum tersedia. Oleh karena itu, perlu dilakukan penelitian untuk mengetahui efek iradiasi terhadap aktivitas sitotoksiknya. Untuk mengetahui pengaruh iradiasi terhadap aktivitas sitotoksik serbuk hipokotil sarang semut (Myrmecodia pendans Merr. \& Perry) dapat dilakukan dengan menggunakan sel leukemia L1210. Pada penelitian ini akan dipelajari profil kromatogram fraksi aktif dengan menggunakan metode Kromatografi Lapis Tipis (KLT), spektrofotometri UV-VIS dan Kromatografi Cair Kinerja Tinggi (KCKT). 


\section{BAHAN DAN METODE}

\section{Bahan penelitian}

Umbi sarang semut (Myrmecodia pendans Merr. \& Perryl diperoleh dari Balitro, Bogor. Bahan kimia yang digunakan terdiri dari $n$-heksan, etil asetat, etanol, metanol, kloroform, RPMI-Medium 1640 (Gibco), tryphan blue, calf bovine serum (Gibco), silika gel 60 mesh (70-230), celite 545 , lempeng silika $\mathrm{GF}_{254}$, larutan penampak bercak serium sulfat $1 \%$ dalam $\mathrm{H}_{2} \mathrm{SO}_{4} 10 \%$, metanol HPLC. Persediaan sel leukemia L1210 yang digunakan dalam uji ini diperoleh dari The Institute of Physical and Chemical Research (RIKEN), Jepang (11).

\section{Peralatan}

Iradiator Karet Alam (IRKA) PAIR BATAN sebagai sumber radiasi gamma, kromatograf cair kinerja tinggi (Shimadzu CR4A), spektrofotometer UV-VIS (HP8453), densitometer (camag), timbangan analitik, mikroskop (Nikon HFX-DX), inkubator $\mathrm{CO}_{2}$, oven, otoklaf, penguap putar vakum/rotavapor (EYELA dan BUCHI), peralatan untuk kromatograf kolom, lampu UV (254 nm), pemanas listrik (hot plate), pencucian ultrasonik, alat-alat gelas, multi well plate tissue's culture, sero cluster plate dan haemocytometer Neubauer improved.

\section{Metode penelitian}

\section{Persiapan sampel dan Iradiasi dengan sumber gamma ${ }^{60} \mathrm{Co}$}

Bahan penelitian yang digunakan dalam penelitian ini adalah umbi sarang semut yang sudah dikeringkan, diserbukkan, dan ditimbang. Sebanyak 10 buah kantong plastik polietilen masingmasing berisi umbi sarang semut seberat 100 gram ditutup rapat dengan sealer matic. Sampel diiradiasi dengan gamma dari sumber ${ }^{60} \mathrm{Co}$ pada dosis $5 ; 7,5 ; 10 ; 15 \mathrm{kGy}$, masing-masing dosis dilakukan 2 kali ulangan.

\section{Pembuatan ekstrak secara maserasi}

Sebanyak lebih kurang 100 gram ekstrak sarang semut diekstraksi secara maserasi 4 kali, tiap kali dengan $600 \mathrm{ml}$ pelarut $n$-heksan yang sama dari maserasi yang pertama hingga maserasi yang keempat, yang sebelumnya dipisahkan antara filtrat dan ampas. Selanjutnya ampas diekstraksi kembali secara maserasi 4 kali, tiap kali dengan $600 \mathrm{ml}$ pelarut etil asetat yang sama dari maserasi yang pertama hingga maserasi yang keempat yang sebelumnya di pisahkan antara filtrat dan ampas. Selanjutnya ampas diekstraksi kembali secara maserasi 4 kali, tiap kali dengan $600 \mathrm{ml}$ pelarut etanol yang sama dari maserasi yang pertama hingga maserasi yang keempat yang sebelumnya di pisahkan antara filtrat dan ampas. Selanjutnya filtrat $n$-heksan, etil asetat, dan etanol dipekatkan dengan menggunakan rotavapor pada suhu lebih kurang $40^{\circ} \mathrm{C}$ hingga diperoleh ekstrak kental. Ekstrak kental tersebut kemudian di vakum hingga diperoleh bobot konstan.

\section{Uji aktivitas sitotoksik ekstrak terhadap sel leukemia L1210}

Pengujian aktivitas sitotoksik dilakukan terhadap ekstrak n-heksan, etil asetat, dan etanol yang diperoleh dari sampel kontrol, dilakukan dengan variasi konsentrasi 5, 10, 20, 40, dan $80 \mu \mathrm{g} / \mathrm{ml}$. Metode pengujian aktivitas sitotoksisitas sampel terhadap sel leukemia L1210 dilakukan dengan metode pembacaan langsung (11).

\section{Fraksinasi ekstrak paling aktif dengan kromatografi kolom}

Ekstrak paling aktif difraksinasi dengan kromatografi kolom menggunakan adsorben (fase diam) silika gel 60 (70-230 mesh). Pemisahan dilakukan dengan pengeluasi sistem landaian diklrometanmetanol dengan berbagai variasi perbandingan dan metanol, masing-masing fraksi ditampung lebih kurang $150 \mathrm{ml}$. Fraksi-fraksi yang diperoleh, masing-masing dikeringkan kemudian divakum hingga diperoleh bobot konstan. 
Analisis Kromatografi Lapis Tipis (KLT) Fraksi-fraksi hasil fraksinasi kolom dari sampel kontrol selanjutnya dianalisis dengan KLT pada lempeng silika gel $\mathrm{GF}_{254}$ kemudian dieluasi dengan eluen yang sesuai. Setelah itu bercak diamati di bawah lampu UV $254 \mathrm{~nm}$ dan $366 \mathrm{~nm}$. Lempeng disemprot dengan pereaksi serium sulfat $1 \%$ dalam $10 \%$ asam sulfat lalu dipanaskan dengan pemanas listrik (hot plate) hingga terbentuk bercak tetap. Fraksi - fraksi dengan pola yang sama digabung sehingga dapat disederhanakan menjadi 7 fraksi. Analisis KLT juga dilakukan terhadap fraksi aktif dari masing-masing sampel yang diiradiasi dan kontrol yang diperoleh dari hasil uji aktifitas sitotoksik terhadap sel leukemia L1210.

Uji aktivitas sitotoksik fraksi aktif dari sampel yang tidak diiradiasi terhadap sel leukemia L1210

Pengujian aktivitas sitotoksik terhadap sel leukemia L1210 dilakukan untuk fraksifraksi dari sampel kontrol yang dibuat dengan variasi konsentrasi $1,2,4,8$, dan 16 $\mu \mathrm{g} / \mathrm{ml}$. Penentuan aktivitas sitotoksik dilakukan dengan metode yang sama dengan uji aktivitas sitotoksisitas sampel mahkota dewa (11). Masing-masing konsentrasi ditempatkan dalam multiwell plate tissue's culture 24 sumuran yang berisi $1 \mathrm{ml}$ suspensi sel leukemia L1210 (mengandung $2 \times 10^{5}$ sel) dalam medium RPMI-1640 yang mengandung calf bovine serum, kemudian diinkubasi dalam inkubator $5 \% \mathrm{CO}_{2}$ pada suhu $37{ }^{\circ} \mathrm{C}$ selama 48 jam. Jumlah sel yang masih hidup dihitung dengan mikroskop. Aktivitas sitotoksik yang merupakan kemampuan sampel uji dalam menghambat pertumbuhan sel dinyatakan dalam persentase $(\%)$ inhibisi berdasarkan rumus:

$$
\% \text { inhibisi }=\left(1-\frac{A}{B}\right) \times 100 \%
$$
$A=$ jumlah sel hidup dalam medium yang mengandung zat yang diuji
$B=$ jumlah sel hidup dalam kontrol

Nilai IC $_{50}$ (inhibitory concentration fifty), yaitu konsentrasi zat uji yang dapat menghambat pertumbuhan sel sebesar 50\%, dihitung dari kurva regresi linier antara log konsentrasi zat uji dengan nilai probit aktivitas penghambatan. Fraksi paling aktif berpotensi antikanker dianalisis lebih lanjut untuk melihat profil kromatogramnya.

\section{Analisis KLT - Densitometri dari fraksi dan ekstrak paling aktif}

Fraksi 1 dan ekstrak etanol dengan dosis $0 ; 5 ; 7,5 ; 10 ; 15 \mathrm{kGy}$, masing-masing ditimbang dengan berat yang sama. Kemudian $40 \mu \mathrm{l}$ ditotolkan pada lempeng silika gel $\mathrm{GF}_{254}$ dan dieluasi dengan diklorometan : metanol (30:1) dan $\mathrm{CHCL}_{3}$ : metanol : air (6:4:1). Selanjutnya hasil eluasi dianalisis dengan densitometer pada panjang gelombang $210 \mathrm{~nm}$ dengan jarak rambat 10 $\mathrm{cm}$ untuk mengetahui luas bercak masingmasing kromatogram dari KLT fraksi 1 dan ekstrak etanol.

\section{Analisis kualitatif fraksi paling aktif secara spektrofotometri UV-VIS}

Semua larutan fraksi aktif dengan konsentrasi yang sama dari sampel yang tidak dan yang diiradiasi dianalisis secara kualitatif dengan spektrofotometer ultraviolet-cahaya tampak pada panjang gelombang $190 \quad-780 \mathrm{~nm}$ untuk menghasilkan spektrum serapan sehingga mengetahui panjang gelombang maksimal dan dapat membandingkan serapan dari masing-masing dosis yang tidak diiradiasi (kontrol) dan yang telah diiradiasi.

\section{Pemeriksaan profil kromatogram KCKT fraksi 1}

Fraksi 1 dari semua sampel baik kontrol $(0 \mathrm{kGy})$ maupun yang diiradiasi diperiksa menggunakan KCKT. Fraksi 1 seberat $1 \mathrm{mg}$ dilarutkan dengan pelarut metanol sehingga konsentrasinya $1 \mathrm{mg} / \mathrm{ml}$. Sebanyak $20 \mu \mathrm{l}$ larutan uji diinjeksikan ke KCKT (kolom C-18). Kondisi terbaik KCKT pada $\lambda 210 \mathrm{~nm}$ menggunakan fase gerak metanol : air ( $8: 2)$, kecepatan alir eluen 
$0,4 \mathrm{ml} /$ menit, dan volume injeksi sebesar 20 $\mu \mathrm{l}$.

\section{HASIL DAN PEMBAHASAN}

\section{Pembuatan Ekstrak dan pengujian sitotoksisitas ekstrak terhadap sel L1210}

Bubuk kasar umbi sarang semut dibungkus dalam kantong plastik poli etilen dengan berat masing-masing 100 gram baik kontrol $(0 \mathrm{kGy})$ maupun yang telah diiradiasi dengan dosis $5 ; 7,5 ; 10$; dan 15 kGy menghasilkan bobot ekstrak etanol memiliki rendemen yang paling banyak dari $2,32 \%$ s.d $2,44 \%$ dibandingkan ekstrak $n$ heksan dan etil asetat. Dari hasil maserasi sampel kontrol dan yang telah diradiasi, berat masing-masing ekstrak menunjukkan bahwa iradiasi tidak berpengaruh terhadap bobot ekstrak yang diperoleh. Aktivitas sitotoksisitas ekstrak sarang semut (kontrol) dalam pelarut $n$-heksan, ekstrak etil asetat dan ekstrak etanol masing-masing mempunyai nilai $\mathrm{IC}_{50} 23,44 ; 17,32$ dan 9,88 $\mathrm{g} / \mathrm{mL}$ terhadap pertumbuhan sel leukemia L1210. Hal ini dilakukan karena belum ada literatur yang melaporkan hal ini sebelumnya, sehingga uji aktivitas sitotoksik ini dilakukan sebagai dasar pemilihan ekstrak paling aktif untuk pengujian selanjutnya. Ekstrak etil asetat dan ekstrak etanol umbi sarang semut memiliki aktivitas sitotoksik terhadap sel leukemia L1210 sesuai persyaratan ekstrak berpotensi anti kanker adalah yang memiliki nilai $\mathrm{IC}_{50} \leq 20$ $\mu \mathrm{g} / \mathrm{mL}$ dinyatakan aktif menghambat pertumbuhan sel leukemia (12). Ekstrak etanol lebih aktif dibandingkan dengan ekstrak etil asetat, karena memiliki nilai $\mathrm{IC}_{50}$ paling kecil. Kedua ekstrak tersebut mengandung metabolit-metabolit sekunder yang saling bersinergi dan berpotensi sebagai antikanker yang dapat menghambat pertumbuhan sel leukemia L1210. Berdasarkan pelarut pengekstraknya etanol, maka metabolit-metabolit sekunder tersebut bersifat hidrofilik atau semipolar dan polar. Senyawa hidrofilik diekstraksi menggunakan pelarut polar seperti metanol, etanol atau air
(13). Hal ini sesuai dengan kondisi sebenarnya konsumen minum air rebusan simplisia kering umbi sarang semut (bersifat polar) dan hasil rebusannya diminum sebagai obat (berkhasiat secara empiris turun temurun). Ekstraksi flavonoid dari bitter melon (buah sebagai obat tradisional) telah dilakukan dalam pelarut polar etanol, methanol, n-butanol, aseton dan air (14). Selanjutnya ekstrak etanol dipilih sebagai ekstrak paling aktif sitotoksisnya. Ekstrak etanol difraksinasi dengan menggunakan kromatografi kolom.

\section{Fraksinasi Ekstrak Etanol dengan Kromatografi Kolom dan Aktivitas Sitotoksik Fraksi-Fraksi dari umbi sarang semut terhadap Sel Leukemia L1210}

Semua ekstrak paling aktif (ekstrak etanol) yang diperoleh dari sampel yang tidak dan yang diiradiasi dilanjutkan dengan fraksinasi. Masing-masing dari hasil fraksinasi ekstrak paling aktif (ekstrak etanol) diperoleh 7 fraksi. Dari 7 fraksi tersebut, fraksi mana yang paling aktif menghambat pertumbuhan sel leukemia L1210, hanya diuji aktivitasnya fraksi-fraksi yang berasal dari sampel tidak diiradiasi. Bila telah diketahui fraksi yang paling aktif berdasarkan hasil pengujian fraksi-fraksi dari sampel kontrol (tidak diiradiasi), maka untuk membandingkan efek radiasi terhadap aktivitas anti kanker sampel umbi sarang semut pada berbagai dosis iradiasi, cukup dipilih fraksi paling aktif yang diuji aktivitasnya. Hal ini cukup untuk melihat apakah ada perubahan aktivitas sitotoksik yang bermakna akibat iradiasi umbi sarang semut, tidak perlu menentukan nilai $\mathrm{IC}_{50}$ ke tujuh fraksi dari semua sampel yang diiradiasi.

Hasil pengujian aktivitas sitotoksik ekstrak dilakukan pada fraksi 1 s.d 7 dengan variabel konsentrasi $1,2,4,8$ dan $16 \mu \mathrm{g} / \mathrm{ml}$ dan metanol sebagai kontrol. Perhitungan $\%$ inhibisi ditransformasi ke nilai probit sebagai sumbu $\mathrm{Y}$ dan log konsentrasi ekstrak sebagai sumbu $X$, sehingga diperoleh persamaan garis linier yang 
ditampilkan pada Gambar 1. Berdasarkan persamaan garis linear ini nilai $\mathrm{IC}_{50}$ dapat diperoleh dari anti log konsentrasi $\mathrm{IC}_{50}$ pada nilai probit 5 . dalam sarang semut telah dibuktikan berfungsi sebagai antioksidan dan dapat mencegah penyakit kanker (15). Tumbuhan sarang semut mengandung senyawa

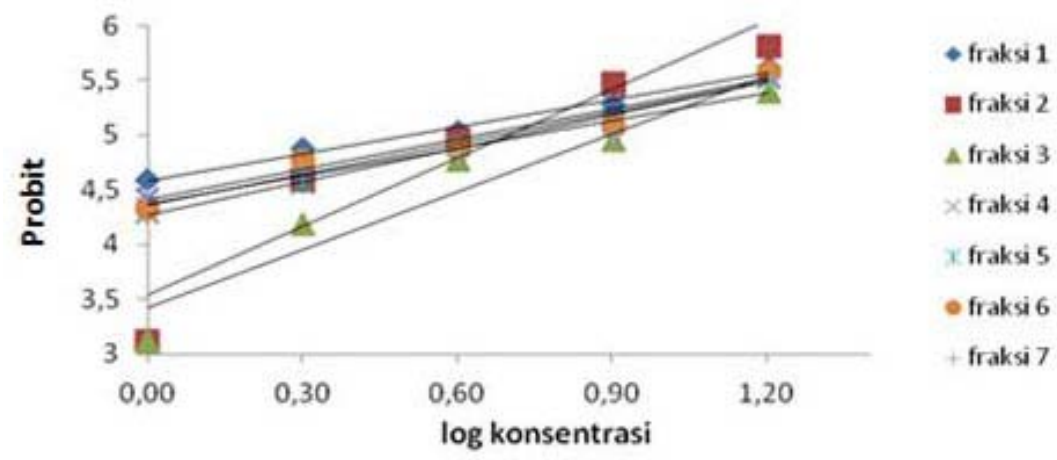

Gambar 1. Grafik antara log konsentrasi dan probit fraksi 1 s.d 7 ekstrak etanol

Berdasarkan hasil uji sitotoksisitas fraksi 1 s.d 7 dari umbi sarang semut yang tidak diiradiasi diperoleh nilai $\mathrm{IC}_{50}$ berturutturut 3,$23 ; 5,04 ; 7,85 ; 4,29 ; 5,26 ; 4,80$; dan $5,47 \mu \mathrm{g} / \mathrm{ml}$, semua fraksi tergolong sangat aktif karena $\mathrm{IC}_{50} \leq 20 \mu \mathrm{g} / \mathrm{ml}$ (12). Fraksi 1 merupakan fraksi yang paling aktif dibandingkan dengan ke-6 fraksi lainnya, karena memiliki nilai $\mathrm{IC}_{50}$ paling kecil yaitu $3,23 \mu \mathrm{g} / \mathrm{ml}$. Fraksi 1 sampai fraksi 7 berwarna hijau kekuningan, diduga banyak mengandung metabolit sekunder yang bersifat semi polar seperti flavonoid dan polifenol yang sangat banyak terdapat dalam umbi sarang semut. Flavonoid dan polifenol metabolit sekunder berupa flavonoid dan tanin (2). Menurut Ren et.al dalam Medicinal research Reviews yang dikutip oleh Fatmawati bahwa flavonoid berperan dalam inaktivasi karsinogen, antiproliferasi, penghambatan siklus sel, induksi apoptosis dan diferensiasi, inhibisi angiogenesis, dan pembalikan resistensi multi-obat atau kombinasi dari mekanisme tersebut (16).

Selanjutnya uji aktivitas sitotoksik fraksi terhadap pertumbuhan sel leukemia L1210 dipilih fraksi paling aktif saja (fraksi 1) dari sampel yang diiradiasi dibandingkan dengan kontrol (Gambar 2).

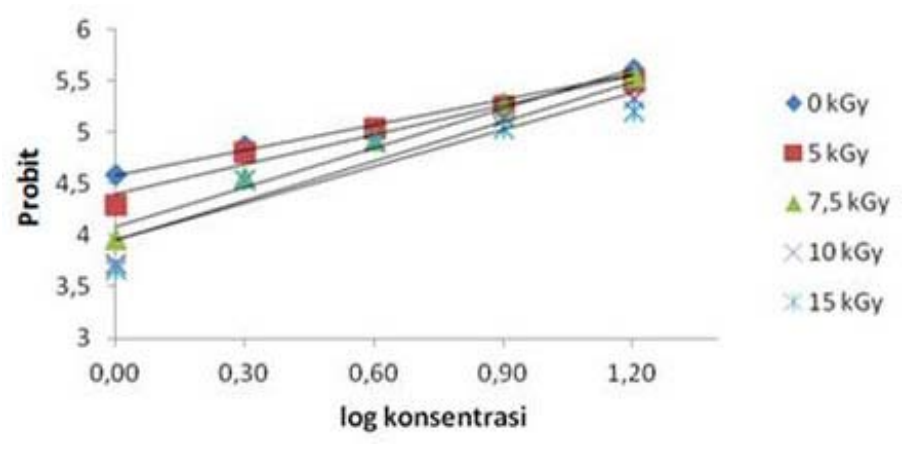

Gambar 2. Grafik antara log konsentrasi dan probit fraksi 1 ekstrak etanol dari umbi sarang semut yang tidak dan yang diiradiasi gamma 
Hasil analisis data $\mathrm{IC}_{50}$ fraksi aktif dari ekstrak etanol dengan uji anova satu arah menggunakan SPSS 16 pada taraf kepercayaan $95 \%(\alpha=0,05)$ pada Gambar 3 menunjukkan bahwa tidak ada perbedaan aktivitas sitotoksik yang bermakna antara kontrol dengan dosis $5 \mathrm{kGy}$, namun menunjukkan ada perbedaan yang bermakna antara kontrol dengan dosis 7,5 , 10 dan $15 \mathrm{kGy}$. Perbedaan bermakna mulai dosis $7,5 \mathrm{kGy}$ ini diduga disebabkan adanya efek langsung iradiasi gamma (8) pada komponen yang ada dalam umbi sarang semut menimbulkan radikal-radikal bebas. Radikal bebas ini ditangkap oleh senyawa yang bersifat antioksidan seperti flavoniod, sehingga dampak peningkatan dosis iradiasi gamma pada senyawa-senyawa golongan flavonoid akan direduksi karena flavonoid menangkap radikal bebas (16...17). Walaupun dosis 7,5 kGy berbeda bermakna terhadap control, namun komponen dalam fraksi 1 ini relatif stabil/tangguh akibat iradiasi gamma, ditunjukkan dengan aktivitas sitotoksik nilai $\mathrm{IC}_{50}$ fraksi 1 yang jauh di bawah $20 \mathrm{~g} / \mathrm{ml}$. dan kimia pada komponen aktif (senyawa golongan flavonoid) yang dapat menyebabkan semakin menurunnya bioaktivitas senyawa tersebut. Perubahan kimia yang terjadi, senyawa flavonoid akan menyumbang elektron bebasnya kepada radikal bebas, sehingga radikal bebas tersebut membentuk senyawa yang stabil (17). Berdasarkan data analisis statistik tersebut, maka dapat disimpulkan bahwa dosis iradiasi gamma untuk serbuk kering umbi sarang semut yang tidak merusak aktivitas sitotoksiknya terhadap sel leukemia L1210 adalah $5 \mathrm{kGy}$.

\section{Profil Kromatogram Lapis Tipis dari Ekstrak Etanol dan Fraksi Aktif}

Hasil kromatogram dari Kromatografi Lapis Tipis (KLT) ekstrak etanol dan fraksi 1 berturut-turut ditunjukkan pada Gambar 4 dan Gambar 5. Pada Gambar 4 ditunjukkan bahwa pada ekstrak etanol dari umbi sarang semut yang tidak diiradiasi terdapat 4 bercak, demikian pula pada dosis $5 \mathrm{kGy}$ tidak ada perubahan pola bercak akibat iradiasi gamma. Namun mulai dosis 7,5 kGy

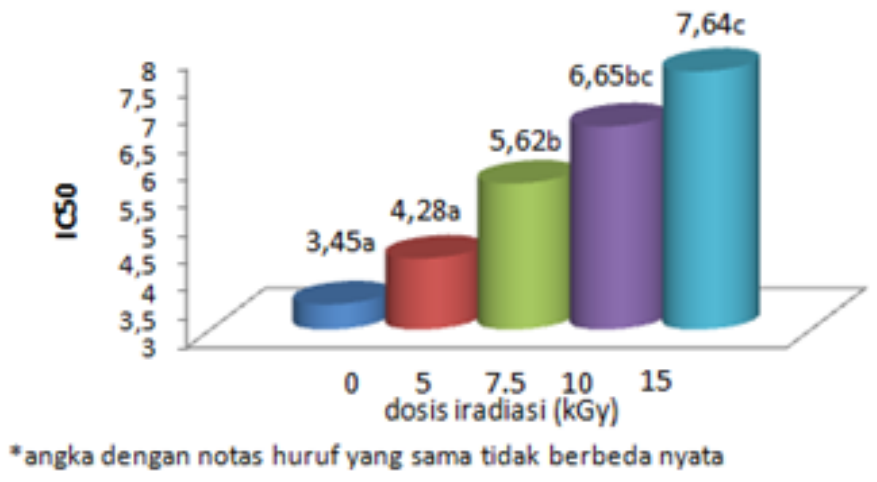

Gambar 3. Diagram batang pengaruh dosis radiasi pada fraksi 1 ekstrak etanol

Aktivitas sitotoksik fraksi 1 pada dosis $\geq 7,5 \mathrm{kGy}$ terjadi penurunan, hal ini diduga karena adanya efek langsung radiasi berupa ionisasi pada materi tersebut dimana semakin besar dosis yang diberikan semakin besar daya ionisasinya. Hal ini akan menyebabkan terjadinya perubahan fisika sampai dengan $15 \mathrm{kGy}$ komponen dalam ekstrak etanol mengalami perubahan, warna bercak 2 dan 3 memudar. Hal ini menunjukkan bahwa pada dosis $\geq 7,5 \mathrm{kGy}$ telah terjadi penurunan senyawa komponen yang terkandung dalam umbi sarang semut. 


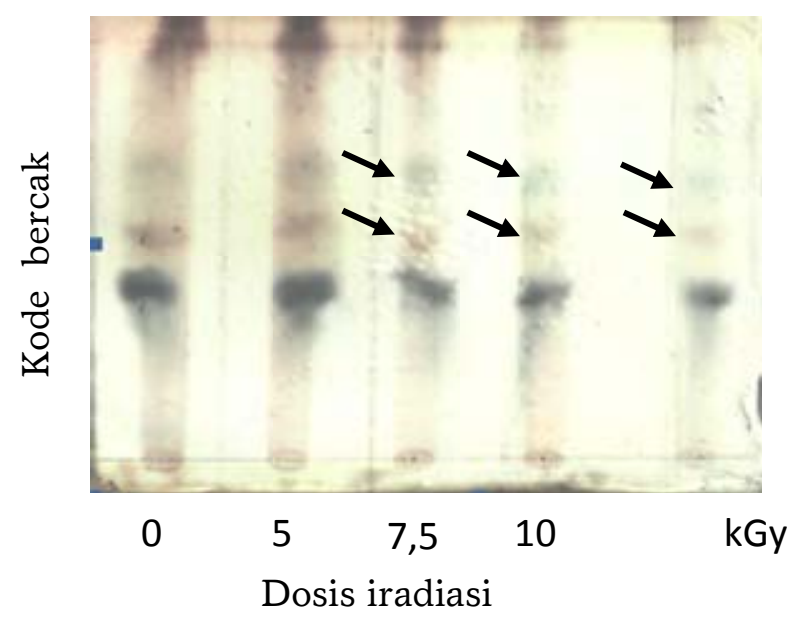

Gambar 4. Kromatogram ekstrak etanol dari umbi sarang semut yang tidak diiradiasi yang dan diiradiasi

Fase Gerak $\quad=$ Kloroform : Metanol : Air $(6: 4: 1)$

Fase diam $\quad=$ Silika gel $\mathrm{GF}_{254}$

Detektor $\quad=$ Sinar UV $254 \mathrm{~nm}$

Penampak bercak = Serium sulfat $1 \%$ dalam $10 \% \mathrm{H}_{2} \mathrm{SO}_{4}$

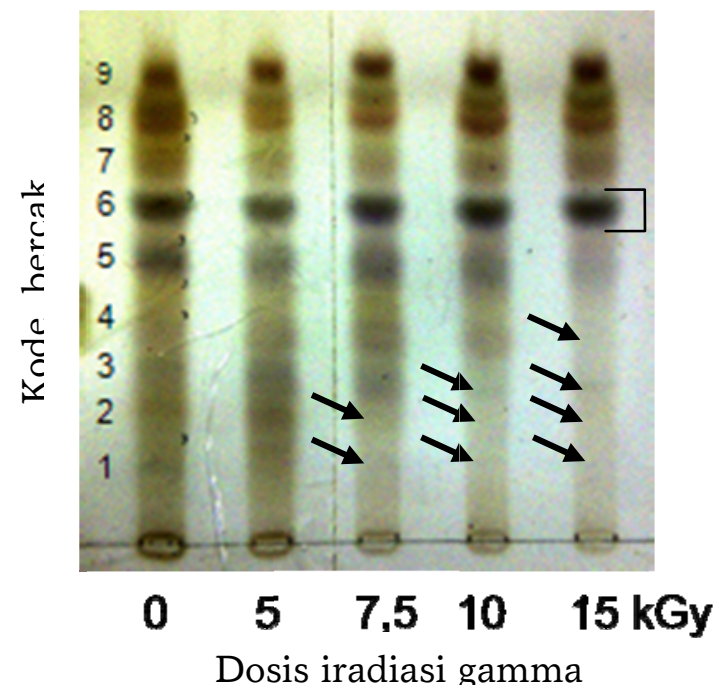

Gambar 5. Kromatogram fraksi 1 dari ekstrak etanol kontrol dan yang telah diiradiasi

Fase gerak $\quad=$ Diklorometan : Metanol (30:1)

Fase diam $\quad=$ Silika gel $\mathrm{GF}_{254}$

Deteksi = Sinar UV 254

Penampak bercak $=$ Serium sulfat $1 \%$ dalam $10 \% \mathrm{H}_{2} \mathrm{SO}_{4}$

Pada Gambar 5, fraksi 1 dari umbi sarang semut yang tidak diiradiasi (kontrol) terdapat 9 bercak. Pada fraksi 1 dari sampel yang iiradiasi dengan dosis $5 \mathrm{kGy}$ tidak mengalami perubahan dibandingkan dengan kontrol, pola KLTnya sama. Pada dosis 7,5 kGy terjadi pemudaran warna bercak 3, bahkan 1 dan 2 tidak muncul; pada dosis 10 
kGy terjadi pemudaran warna pada bercak 1, 2 dan 3. Makin tinggi dosis iradiasi yaitu pada $15 \mathrm{kGy}$, bercak bercak 1, 2, 3 dan 4 tidak muncul. Hal ini menunjukkan bahwa iradiasi gamma menyebabkan komponen pada bercak 1 sampai 4 tidak tahan terhadap iradiasi. Hasil penapisan fitokimia menunjukkan bahwa ekstrak metanol umbi sarang semut mengandung senyawasenyawa golongan flavonoid dan triterpenoid/steroid (18), diduga komponenkomponen ini terdegradasi akibat iradiasi gamma dosis $\geq 7,5 \mathrm{kGy}$, hal ini berkaitan erat dengan aktivitas sitotoksik pada Gambar 3, mulai dosis 7,5 kGy terdapat perbedaan yang nyata nilai $\mathrm{IC}_{50}$ terhadap kontrol. berbeda nyata terhadap kontrol), pada dosis iradiasi > $5 \mathrm{kGy}$ menunjukkan perbedaan yang nyata.

\section{Pemeriksaan KLT - Densitometri dari Ekstrak Etanol dan Fraksi 1}

Pemeriksaan

KLT-Densitometri dilakukan pada panjang gelombang $210 \mathrm{~nm}$ baik sampel kontrol (0 kGy) maupun yang telah diiradiasi (Gambar 6). Profil 3D KLT Densitometer ekstrak etanol dan fraksi 1 menunjukkan terjadinya penurunan, peningkatan area bercak, pembentukan bercak yang baru. Hasil analisis fraksi 1 dengan KLT - Densitometer (Tabel 1) menunjukkan pada dosis $5 \mathrm{kGy}$ terbentuk bercak 4 (blok warna kuning) atau hilang
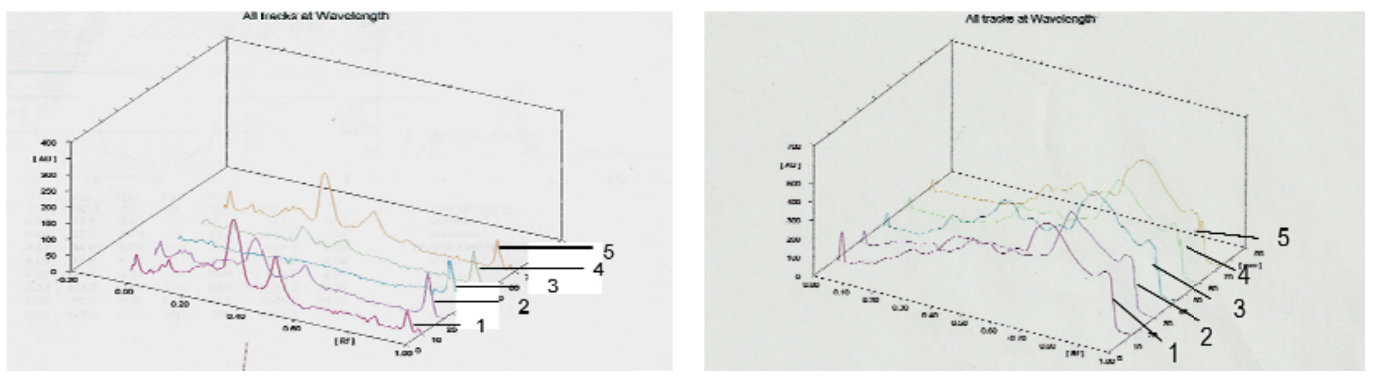

Gambar 6. Profil 3D pada $\lambda 210 \mathrm{~nm}$ ekstrak (a) dan fraksi 1 umbi sarang semut (b)

Keterangan : 1. warna merah untuk dosis $0 \mathrm{kGy}$ (kontrol)

2. warna ungu untuk dosis $5 \mathrm{kGy}$

3. warna biru untuk dosis $7.5 \mathrm{kGy}$

4. warna hijau untuk dosis $10 \mathrm{kGy}$

5. warna kuning untuk dosis $15 \mathrm{kGy}$

Pada makanan yang mengandung karbohidrat yang diiradiasi gamma pada dosis pasteurisasi dilaporkan terjadi penurunan jumlah karbohidrat sebesar 5\%, pada makanan kucing (kering) karbohidrat dari $446 \mathrm{~g} / \mathrm{kg}$ turun menjadi $435 \mathrm{~g} / \mathrm{kg}$ (19). Sarang semut mengandung karbohidrat 78,8 g/100 g sarang semut (2), karbohidrat sangat peka terhadap iradiasi gamma, sesuai syarat iradiasi gamma untuk makanan yang mengandung karbohidrat dosis iradiasi maksimum 5 kGy (20). Hal ini didukung oleh nilai $\mathrm{IC}_{50}$ fraksi 1 dari ekstrak etanol umbi sarang semut sebesar 4,28 $\mathrm{g} / \mathrm{ml}$ (tidak bercak 2 dan 10 (tanda *), adanya perubahan ini disebabkan energi iradiasi gamma yang mengubah komponen dalam fraksi 1. Peningkatan area pada beberapa bercak diduga akibat degradasi senyawa sehingga membentuk komponen baru, terjadi perubahan dibandingkan dengan kontrol (0 $\mathrm{kGy})$. Hasil fitokimia yang dilakukan oleh Mardani bahwa sarang semut papua mengandung senyawa-senyawa golongan flavonoid, saponin dan tannin (15). Pada dosis 7,$5 ; 10$ dan $15 \mathrm{kGy}$ terjadi beberapa komponen yang hilang dibandingkan dengan kontrol, hal ini diduga 
Tabel 1. data KLT - Densitometri fraksi 1 dari ekstrak etanol

\begin{tabular}{ccccccc}
\hline \multirow{2}{*}{ Bercak } & \multirow{2}{*}{$\mathrm{Rf}$} & \multicolumn{5}{c}{ Area bercak pada dosis } \\
\cline { 3 - 7 } & & $0 \mathrm{kGy}$ & $5 \mathrm{kGy}$ & $7,5 \mathrm{kGy}$ & $10 \mathrm{kGy}$ & $15 \mathrm{kGy}$ \\
\hline 1 & $0,02-0,05$ & 1460.2 & 589,0 & 489,3 & 372,5 & 309,2 \\
2 & $0,06-0,09$ & 518,9 & $*$ & $*$ & $*$ & 344,6 \\
3 & $0,10-0,15$ & 553,5 & 1960,2 & $*$ & $*$ & $*$ \\
$\mathbf{4}$ & $0,16-0,20$ & - & 2221,8 & - & - & - \\
5 & $0,21-0,30$ & 10234,5 & 4394,6 & 9373,5 & 1116,1 & 1218,9 \\
6 & $0,40-0,44$ & 27351,3 & 13366,3 & 19613,4 & 10963,4 & 12159,0 \\
7 & $0,45-0,50$ & 11892,7 & 6066,7 & $*$ & 5880,2 & 5518,0 \\
8 & $0,51-0,55$ & 13742,0 & 8164,5 & 12892,6 & 9671,4 & 16813,0 \\
$\mathbf{9}$ & $0,56-0,60$ & - & - & - & 3312,7 & - \\
10 & $0,61-0,70$ & 18265,0 & $*$ & 13658,6 & $*$ & 12756,0 \\
11 & $0,72-0,75$ & 78089,2 & 67703,5 & 60440,2 & 68420,8 & 70656,7 \\
12 & $0,90-0,92$ & 15562,7 & 15097,2 & 14291,2 & 12133,8 & 10471,0 \\
$\mathbf{1 3}$ & $0,93-0,95$ & - & - & - & 2086,3 & 26792,2 \\
\hline
\end{tabular}

akibat iradiasi gamma pada senyawasenyawa golongan flavonoid, saponin atau tanin mengalami degradasi $\left({ }^{*}\right)$ dan membentuk komponen baru (di blok warna kuning). Secara umum hasil analisis fraksi 1 dengan KLT - Densitometer menunjukkan adanya penurunan, peningkatan area bercak, bahkan ada bercak yang terbentuk (Tabel 1). Pada dosis 7,5 kGy mengalami penurunan area bercak dibandingkan kontrol. Pada dosis $10 \mathrm{kGy}$ telah terjadi penurunan area dibandingkan dengan kontrol dan terbentuk bercak 9 dan 13 (diblok kuning). Pada dosis 7,5 dan $10 \mathrm{kGy}$ terjadi beberapa komponen yang hilang dibandingkan dengan kontrol $\left({ }^{*}\right)$, hal ini diduga diakibatkan rusaknya senyawa akibat iradiasi dan kemungkinan terbentuk senyawa baru hasil degradasinya. Pada dosis $15 \mathrm{kGy}$ pada bercak 8 terjadi peningkatan area bercak dan terbentuk bercak 13 (diblok kuning). Hasil degradasi ini juga dapat meningkatkan nilai serapan pada Rf (Retention factor) tertentu. Moosavi melaporkan bahwa iradiasi gamma 2 sampai $10 \mathrm{kGy}$ menurunkan kadar total fenolat dan flavonoid pada almond hull (kulit buah) (22). Suhaj juga melaporkan bahwa efek iradiasi gamma dapat menurunkan kadar tannin dan aktivitas radical-scavanging ekstrak lada hitam (23). Dosis 15 kGy menyebabkan terjadi peningkatan area pada bercak 8 dan terbentuk bercak 13. Secara keseluruhan iradiasi gamma mempengaruhi beberapa komponen dalam fraksi 1 pada $5 \mathrm{kGy}$ sampai dosis $15 \mathrm{kGy}$. Namun berdasarkan hasil uji aktivitas sitotoksik, dosis $5 \mathrm{kGy}$ tidak mengubah aktivitas sitotoksik umbi sarang semut (Gambar 3).

Kromatogram fraksi 1 pada panjang gelombang 254 dan $366 \mathrm{~nm}$ dari sampel yang diiradiasi dan tidak diiradiasi pada panjang gelombang 254 dan $366 \mathrm{~nm}$ disajikan pada Gambar 7. Bercak yang dihasilkan pada $\lambda 366 \mathrm{~nm}$ menghasilkan 10 bercak sedangkan pada $\lambda 254 \mathrm{~nm}$ hanya tampak 5 bercak. Pada Gambar $7 \mathrm{~b}$, bercak 5 dan 9 berflourosensi (bercak berwarna biru muda) menunjukkan bahwa fraksi 1 mengandung senyawa-senyawa golongan flavonoid (21). Secara umum iradiasi gamma mempengaruhi keberadaan beberapa komponen (tanda panah) dalam fraksi 1 dari 7,5 kGy sampai dosis $15 \mathrm{kGy}$ (bercak 1 dan 2 pada Gb. $7(a)$; bercak 1 sampai 7 pada Gb. 7 (b)). Bercak 6 dan 7 mulai dosisi 5 kGy juga mengalami pemudaran, namun berdasarkan hasil uji aktivitas sitotoksik umbi sarang semut pada dosis $5 \mathrm{kGy}$ 

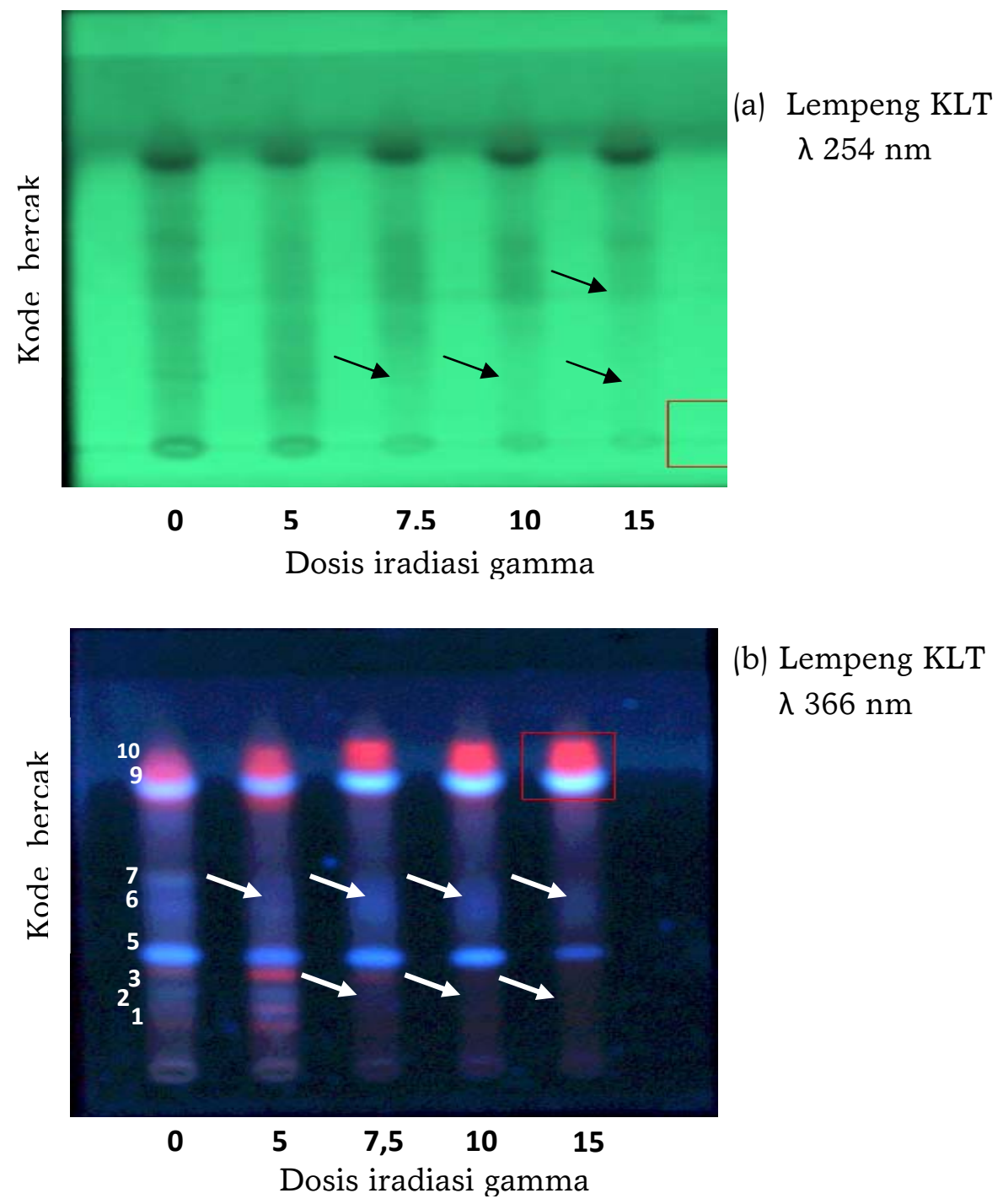

Gambar 7. Foto kromatogram fraksi 1 etanol dari kontrol dan yang telah diiradiasi

menunjukkan bahwa tidak ada perbedaan bermakna dibandingkan kontrol (Gambar 3).

\section{Analisis kualitatif Fraksi 1 dengan Spektrofotometer UV-VIS}

Pemeriksaan serapan dengan spektrofotometer UV-VIS (pada pada panjang gelombang $202 \mathrm{~nm}$ ) dilakukan terhadap fraksi aktif yaitu fraksi 1 semua sampel baik yang diiradiasi maupun yang tidak diiradiasi. Pola serapan tersebut dapat dilihat pada Gambar 8. Serapan pada fraksi 1 umbi sarang semut yang diiradiasi cenderung mengalami penurunan seiring peningkatan dosis, hal ini menunjukkan bahwa iradiasi gamma menyebabkan perubahan serapan komponen yang terdapat dalam fraksi 1 dari ekstrak etanol umbi sarang semut. Berdasarkan hasil KLTdensitometri, fraksi 1 mengandung senyawa golongan flavonoid dibuktikan dengan adanya bercak 5 dan 9 yang berflouresensi (Gambar 7b). Hasil analisis luas puncak berkaitan dengan aktivitas sitotoksik fraksi 1, dimana tidak adanya perbedaan bermakna antara kontrol (0 kGy) dengan dosis $5 \mathrm{kGy}$ namun terdapat perbedaan bermakna pada dosis 7,5 ; 10; dan $15 \mathrm{kGy}$ dibandingkan dengan kontrol. 


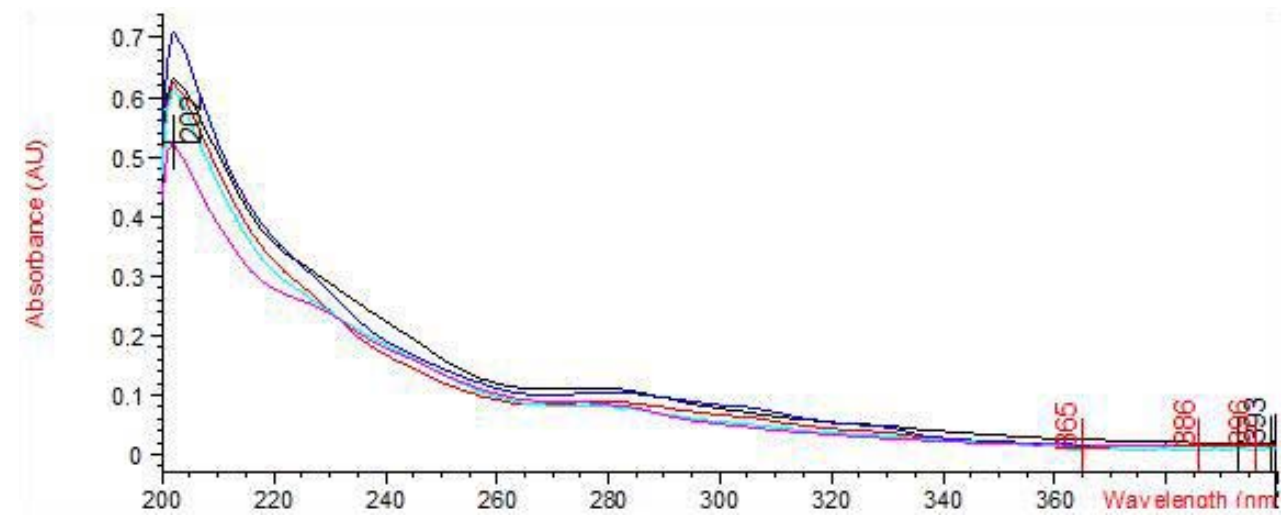

Gambar 8. Spektrum fraksi 1 dari sarang semut yang tidak maupun yang diiradiasi gamma

\section{Analisis Profil Kromatografi Cair} Kinerja Tinggi (KCKT) terhadap fraksi 1

Analisis KCKT dilakukan pada fraksi 1 dari umbi sarang semut dengan membandingkan profil kromatogram kontrol (0 kGy) dan yang diiradiasi. Kromatogram ditunjukkan pada Gambar 9, sedangkan luas area puncak ditampilkan pada Gambar 10. Kromatogram fraksi 1 pada berbagai dosis $(\alpha=0,05)$, analisis statistik menunjukkan bahwa tidak ada perbedaan yang bermakna antara kontrol dengan dosis $5 \mathrm{kGy}$ namun menunjukkan ada perbedaan yang bermakna terhadap luas puncak 1 pada dosis 7,5 ; 10; dan $15 \mathrm{kGy}$ dibandingkan dengan kontrol. Hal ini diduga adanya degradasi komponen-komponen yang mempunyai serapan pada $\lambda 210 \mathrm{~nm}$, seperti

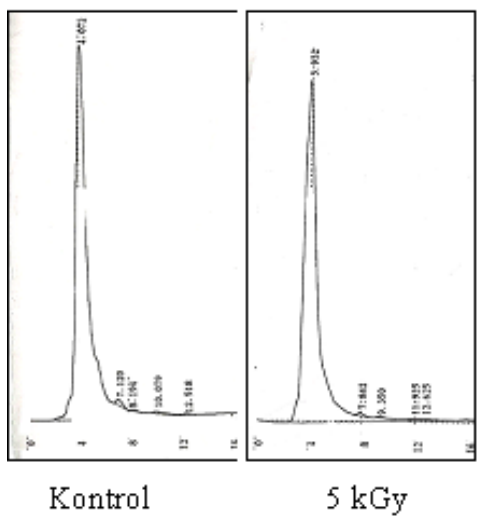

Gambar 9. Kromatogram KCKT fraksi 1

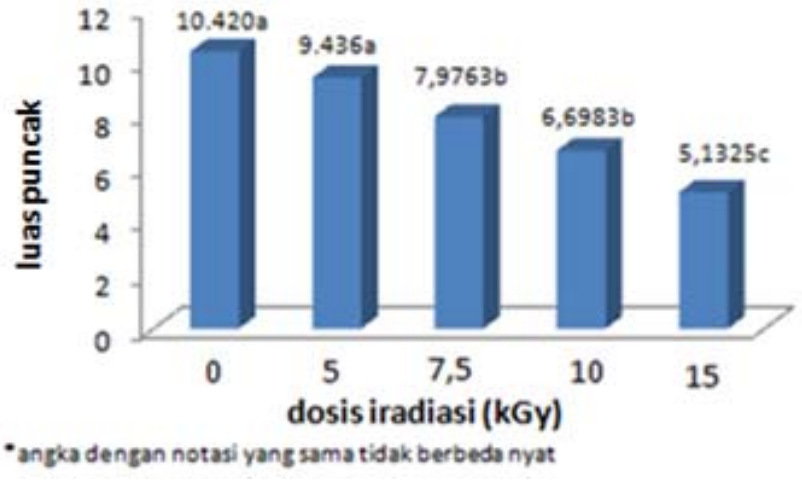

Gambar 10. Diagram batang pengaruh dosis iradiasi pada luas puncak fraksi 1 etanol iradiasi menunjukkan adanya 1 puncak dengan waktu retensi 4 menit. Makin tinggi dosis iradiasi gamma yang diberikan, maka luas puncak makin menurun. Melalui hasil analisis statistik menggunakan anova satu arah (SPSS 16,0) pada taraf kepercayaan 95\% halnya data KLT-densitometri dan spektrofotometri fraksi 1 sebelumnya.

Hingga saat ini belum ada regulasi khusus yang mengatur iradiasi simplisia obat dan sejenisnya, tetapi menurut Codex Allimentarius Commision JEFCI, iradiasi suatu 
bahan sampai dengan dosis $10 \mathrm{kGy}$ aman untuk dikonsumsi (24). Hasil analisis luas puncak ini berkaitan dengan aktivitas sitotoksik fraksi 1, yang juga mendukung bahwa tiadak ada perbedaan bermakna antara kontrol (0 kGy) dengan dosis $5 \mathrm{kGy}$ namun terdapat perbedaan bermakna pada dosis 7,$5 ;$ 10; dan $15 \mathrm{kGy}$ dibandingkan dengan kontrol (0 kGy). Dengan demikian dosis 5 kGy merupakan dosis maksimum untuk pengawetan umbi sarang semut dengan iradiasi gamma.

\section{KESIMPULAN}

Dari hasil maserasi bertahap umbi sarang semut diperoleh ekstrak n-heksan, etil asetat dan etanol, ekstrak yang paling aktif adalah ekstrak etanol dengan nilai $\mathrm{IC}_{50}$ sebesar 9,88 $\mu \mathrm{g} / \mathrm{mL}$, sedangkan fraksi 1 merupakan fraksi paling aktif dari 7 fraksi yang diperoleh dengan nilai $\mathrm{IC}_{50}$ sebesar $3,23 \mu \mathrm{g} / \mathrm{ml}$. Iradiasi gamma dosis $5 \mathrm{kGy}$ tidak mengubah aktivitas sitotoksik fraksi 1 terhadap sel leukemia L1210 dibandingkan dengan kontrol, tetapi pada dosis $\geq 7,5 \mathrm{kGy}$ mengalami perubahan. Demikian juga profil Kromatogram Lapis Tipis fraksi dari umbi sarang semut yang diiradiasi gamma dengan dosis $5 \mathrm{kGy}$ tidak mengalami perubahan, namun dosis $\geq 7,5 \mathrm{kGy}$ mengakibatkan adanya perubahan pada komponenkomponen umbi sarang semut. Berdasarkan hasil pemeriksaan aktivitas sitotoksik fraksi 1 dari umbi sarang semut terhadap sel leukemia L1210, profil spektrum uv, profil kromatogram lapis tipis dan KCKT, dapat disimpulkan bahwa dosis $5 \mathrm{kGy}$ merupakan dosis maksimum untuk iradiasi umbi sarang semut.

\section{DAFTAR PUSTAKA}

1. HARIANA, A., Tumbuhan Obat dan Khasiatnya. Cetakan 4. Jakarta: Penebar swadaya (2008).
2. SUBROTO, MA. dan SAPUTRO, H., Gempur penyakit dengan sarang semut. Jakarta: Penebar Swadaya, 11-32 (2006).

3. BUSTANUSSALAM, Penentuan struktur molekul dari fraksi air tumbuhan "sarang semut" Myrmecodia pendans Merr. \& Perry mempunyai aktivitas sitotoksik dan sebagai antioksidan[tesis]. Institut Pertanian Bogor, 36,44 (2010).

4. Riset ilmiah tumbuhan sarang semut. Diambil dari: http://www.sarangsemut. co.id/hasilriset.html. Di akses pada 1 April 2011.

5. SOEKSMANTO, A., SUBROTO, MA., WIJAYA, $\mathrm{H}$. and SIMANJUNTAK, P., Anticancer Activity Test for Exctract of sarang semut Plant (Myrmecodia Pendens) to HeLa and MCM-B2 Cells. Pakistan J. Biological Sci., 13 (3), 148-151 (2010)

6. HERTIANI, T., SASMITO, E., SUMARDI, dan ULFAH, M., Preliminary study on immunomodulatory effect of sarang-semut hypocotyls Myrmecodia tuberosa and Myrmecodia pendens. Online J. Biol. Sci. 10, 136-141 (2010).

7. WULANSARI, NH., SEJATI, AA., SUPRIATNO, dan INDRAYANTI, Efektifitas ekstrak etanol sarang semut terhadap proliferasi sel kanker lidah manusia (SP-C1) in vitro experimental Study, Prosiding Seminar Ilmiah Nasional Kesehatan, https://publikasiilmiah.ums.ac.id/.../ 11.\%20NURUL\% 2 NURUL HUSNA.pdf, diakses tanggal 30 September 2015.

8. IRAWATI, Z., Aplikasi Mesin Berkas Elektron Pada Industri Pangan. 
Dalam: Prosiding pertemuan dan Presentasi Ilmiah Teknologi Akselerator dan Aplikasinya; Jakarta; BATAN, 87-94 (2006).

9. WINARNO, EK., MAZDA, RAHMAWATI, H., dan WINARNO, H., Pengaruh Iradiasi Gamma pada Aktivitas Sitotoksik Daging Buah Mahkota Dewa (Phaleria macrocarpa (Scheff) Boerl.), J. Sains dan Teknologi Nuklir Indonesia, Indonesian J. Nuclear Sci. And Tech., Xi, (2), 67-76 (2010).

10. KATRIN, E., YULIANTI, M., and WINARNO, H., Effectiveness of Gamma Irradiation for Decontamination of Microbes on Tea Parasite Herb Scurrula atropurpurea (Bl.) Dans. Atom Indonesia, 37 (3), 107 - 112 (2011).

11. WINARNO, H. dan KATRIN, E. Benzophenone glucoside isolated from the ethyl acetate extract of the bark of Mahkota Dewa (Phaleria macrocarpa (Scheff.) Boerl.) and its inhibitory activity on leukemia L1210 cell line, Indo. J. Chem., 8 (1), 142-145 (2009).

12. HOStettmanN, K., Assays Related to Cancer Drug Discovery. In: Assays For Bioactivity, Volume 6, Switzerland: University of Lausanne, Institute of Pharmacognosy and Phytochemistry, 84, (1991).

13. FABRICANT, D.S. and FARNSWORTH, N.R. The value of plants used in traditional medicine for drug discovery. Environ. Health Perspect, 2001, 109, 69-75.

14. TAN, S.P., PARKS, S.E., STATHOPOULOS, C.E., ROACH, P.D., Extraction of Flavonoids from
Bitter Melon, Food and Nutrition Sciences, 2014, 5, 458-465.

15. MARDANY, MP, LINUS Y. CHRYSTOMO, LY, dan KARIM, AK, Skrining Fitokimia dan Uji Aktivitas Sitotoksik dari Tumbuhan Sarang Semut (Myrmecodia beccarii Hook.f.) Asal Kabupaten Merauke, J. Biologi Papua, 8, (1), 13-22 (2016).

16. FATMAWATI, D., PUSPITASARI, PK dan YUSUF, I., Efek Sitotoksik Ekstrak Etanol Sarang Semut (Myrmecodia pendens) pada Sel Line Kanker Serviks HeLa Uji Eksperimental Secara In Vitro Cytotoxic Effect of Ethanolic Extract of Sarang Semut (Myrmecodia pendens) on HeLa Cervix Cancer Cell Line In Vitro Experimental, Study Sains Medika, 3 (2), 112-120 (2011).

17. MELO VAZ, AF, SOUZA, MP, ARGÔLO, ACCM, ALBUQUERQUE MELO, AMM, OLIVA, MLV, XAVIER, HS, COELHO, LCBB, and SANTOS CORREIA, MT, Stability of the Antioxidant Activity of Flavonoids after Gamma Irradiation, Food and Nutrition Sciences, 2011, 2, 490493.

18. DIRGANTARA, S., DEWI, K., RAYA, JN., SIMANJUNTAK, TL., Studi Botani dan Fitokimia Tiga Spesies Tanaman Sarang Semut Asal Kabupaten Merauke, Provinsi Papua, Studi Botani dan Fitokimia Tiga Spesies Tanaman Sarang... journal.wima.ac.id/index.php/JFST/ article/view/.../713. Diakses tgl. 2 Oktober 2015.

19. CAULFIELD, CD., CASSIDY, JP., AND KELLY, JP., Effects of Gamma Irradiation and Pasteurization on the Nutritive Composition of 
Commercially Available Animal Diets, $J$. of the American Association for Laboratory Animal Science, 47 (6), 61-66.

20. KEMENKES RI, Peraturan MenKes RI No. 701/MENKES/PER/VIII/2009 tentang pangan iradiasi, (2009).

21. MUTIATIKUM, D., ALEGANTINA, S. dan ASTUTI, Y., Standarisasi simplisia dari buah miana (Plectranthus Seutellaroides (L.) R. Btlz) yang berasal dari 3 tempat tumbuh menado, kupang dan papua, Puslitbang Biomedis dan Farmasi, Badan Penelitian dan Pengembangan Kesehatan, Standardisasi Simplisia Dari Buah Miana (Plectranthus ... Download.Portalgaruda.Org/Article. Php?Article $=71013 \& \mathrm{Val}=4882$, Diakses tanggal 2 Oktober 2015.

22. MOOSAVI, K.S, HOSSEINI, S., DEHGAN, G., JAHANBANESFAHLAN, A., The effect of gamma irradiation on phytochemical content and antioxidant activity of stored and none stored almond (Amygdalus communis L.) hull, Pharmaceutical Sciences, 20, 102-106 (2014).

23. SUHAJ, M., RACOVA, J., POLOVKA, M., AND BREZOVA, V., Effect of girradiation on antioxidant activity of black pepper (Piper nigrum L.), Food Chem. 2006, 97, 696-704.

24. General Standard For Irradiated Foods Codex. www. Codexalimentarius. Org/Input/Download/Standards/.../C xs_106e.Pdf Page 1 of 3. GENERAL STANDARD FOR IRRADIATED FOODS. CODEX STAN 106-1983, REV.1-SCOPE. This standard applies to foods processed by ionizing radiation that is used in conjunction with applicable hygienic codes, food standards and transportation codes, 2003, 1. Diakses 30 Oktober 2015. 